\title{
Balkanologie
}

Balkanologie Revue d'études pluridisciplinaires

Vol. IX, n' $1-2 \mid 2005$

Volume IX Numéro 1-2

\section{Adapting Mystic Identity to Italian Mainstream Islam: The Case of a Muslim Rom Community in Florence}

L'adaptation de l'identité mystique au courant dominant de l'Islam italien : le cas d'une communauté rom musulmane a Florence

\section{Fabrizio Speziale}

\section{OpenEdition}

Journals

Édition électronique

URL : http://journals.openedition.org/balkanologie/589

DOI : 10.4000/balkanologie.589

ISSN : 1965-0582

Éditeur

Association française d'études sur les Balkans (Afebalk)

Édition imprimée

Date de publication : 1 décembre 2005

ISSN : 1279-7952

Référence électronique

Fabrizio Speziale, « Adapting Mystic Identity to Italian Mainstream Islam: The Case of a Muslim Rom Community in Florence », Balkanologie [En ligne], Vol. IX, n 1-2 | 2005, mis en ligne le 13 janvier 2010, consulté le 17 décembre 2020. URL : http://journals.openedition.org/balkanologie/589; DOI : https:// doi.org/10.4000/balkanologie.589 


\title{
ADAPTING MYSTIC IDENTITY TO ITALIAN MAINSTREAM ISLAM: THE CASE OF A MUSLIM ROM COMMUNITY IN FLORENCE
}

\author{
Fabrizio Speziale*
}

\section{THE MUSLIM ROMA 1}

The religious identity of the Muslim Roma of the Balkans, their oral transmission of the Islamic religious knowledge and tradition, of the Sufi esoteric doctrine and mystical poetry, their affiliation to Sufi orders and the related observance of Shi'a devotional traditions are all subjects that have not received much attention among scholars. This article focuses on a Macedonian Rom community living in a camp situated in the suburbs of Florence (Italy), and led by Shaykh Baba Jevat Rufat Helveti, a shaykh (Sufi master) belonging to the Khalwatiyya order. The purpose of this article is to describe the composite identity of this group of Muslim Roma, made up of different and contrasting layers of cultures and traditions, and the way in which interaction with the local Islamic authorities has contributed to important readjustments in their religious identity and rituals.

Muslim Roma often call themselves Khorakhané, a name related to the Qur'an (khora in Romanè language), most likely meaning " in the way of the Qur'an ". Baba Jevat defines habitually himself and the members of his community as Rom, which along with the Sinti constitute the two main groups of Gypsies who settled in Italy. Rom (pl. : Roma) means " man ", as well as " hus-

\footnotetext{
- Teacher of Anthropology of Religion at the Pontificia Università Gregoriana (Rome). Contact : spezialef@yahoo.com.

${ }^{1}$ The author would like to thank Leonardo Landi, Alexandre Popovic and Nathalie Clayer for their comments on different topics of this paper. On Gypsies in general, see Acton (Thomas), (ed.), Gypsy Politics and Social Change, London : Routledge, 1974 ; Cozannet (François), Gli Zingari. Miti e usanze religiose, Milano : Oscar Mondadori, 1990 [original edition : Mythes et coutumes religieuses des Tsiganes, Paris : Payot, 1973] ; Liégeois (Jean-Pierre), Gypsies : an Illustrated History, London : Al Saqi Books, 1986 [or. ed.: Tsiganes, Paris : La Découverte, 1983] ; Liégeois (Jean-Pierre), Zingari e Viaggianti, Roma : Lacio-Drom, 1987 (ed. or.: Tsiganes et Voyageurs, Strasbourg : Conseil de l'Europe, 1985) ; Ledda (Luisa), Pau (Paola), eds., Gente del mondo. Voci e silenzi delle culture zingare, Roma : Artemide, 1994.
} 
band ", and Roma often refuse to be called "Gypsies ", because this is the name given to them by the Gagi, the non-Rom ${ }^{2}$. Opera Nomadi, an association working with Gypsy populations, estimates that in 2005 there are about 150000 Gypsies in Italy ; 70 ooo of them - Rom, Sinti and Camminanti - are Italian citizens ; 80000 are migrants from Eastern Europe. They migrated to Italy since the late 1960 s, and later in the 1990 s, due to the Yugoslav wars ${ }^{3}$. Most of them are sedentary. There is no statistics available about the Muslim Roma in Italy4. They usually did not care about the rules of identity control proper to sedentary cultures, but they have recently become more aware of the advantages that a status of legal immigrant can provide. A first element that strongly defines the position of Muslim Roma in the Italian society and in the wider Gypsy community is that they constitute only a minority of the Gypsy population living in Italy. They are a minority of a minority, which can be discriminated not only by the surrounding society, but also by the majority of the minority group. Christian Gypsies such as the Sinti settled in Italy since the beginning of the $15^{\text {th }}$ century 5 , while the immigration of Muslim groups became noticeable only in the second half of the $20^{\text {th }}$ century. Almost all groups of Muslim Roma settled in Italy are of Balkan origin ${ }^{6}$. The new waves of migration in the last decades, mostly from Yugoslavia, have increased the size of the Gypsy population living around Italian cities. This demographic growth has contributed to rekindle the social intolerance against Gypsies, especially in the larger cities, and has threatened the integration within the Italian society achieved by the elder and sedentary groups of Gypsies.

The group of Muslim Roma described in this article lives in the northern suburbs of Florence, not far from the airport, in a camp named il Poderaccio. Nearby is another Gypsy camp named Masini. The Poderaccio camp hosts about 300 persons, but no official data are available. The population of the Poderaccio and Masini camps consists of Roma from Macedonia and Kosovo. The Macedonian group is guided by an eminent religious leader, Shaykh Baba Jevat Rufat Helveti, who belongs to the Khalwatiyya order? ${ }^{7}$. His authority is more or

${ }^{2}$ On the different groups and tribes of Gypsies settled in Italy and the origins of their names, see Soustre de Condat (Daniell), Rom, una cultura negata, Palermo : Assessorato agli Incarichi Speciali della Città di Palermo, 1997, especially pp. 2-3, 33-35.

3 Converso (Massimo), Scheda Rom, Sinti e Camminanti, Roma : Opera Nomadi, 2005.

4 The number of regular Muslim immigrants originating from Macedonia is estimated at 4126 in 2000 (La Repubblica, 14/09/00).

5 As early as in November 1547 there is a ban of the Signoria di Firenze against Gypsy men and women.

${ }^{6}$ Campani (Giovanna), "Flux Migratoires des Balkans en Italie ", Homme et Migration, (1205), janvier-février 1997.

7 He calls himself also a karabash, but this, as remarked by Nathalie Clayer, should not be considered as an association with the Karabashiyya branch of the Khalwatiyya, but it is rather an epithet (likely connected to the black colour turban worn by the shaykh) used in the Ramazaniyya, at least from the be- 
less acknowledged by the whole Poderaccio camp. He has initiated many residents of the camp (both from Macedonia and Kosovo), as well as some Italians, into the Khalwatiyya. Before describing the activities of this group and its interactions with the local Islamic authorities, however, it is necessary to point out a few basic features of the traditional identity of Muslim Roma.

The composite structure of the Khorakhane social and religious identity may be considered as made of two main cultural traditions : the Rom one and the Muslim one. The Rom identity is actually an aggregate of different cultural layers coming from the Indian setting (India being Gypsys' land of origin), the nomadic culture, and all those features that have been acquired by the Rom during their migrations and contacts with various Asian and European populations. Gypsies are distributed nowadays in various regions of the Islamic world, or of what was part of the Islamic world, such as in the case of the Balkans. According to a well-known legend, their migration from India started before Islam, and the first country they migrated to, as artists, was preIslamic Iran, at the request of the Sasanid king Bahram Gur (420-438). In the famous historic and epic works by Hamza al-Isfahani (10 $10^{\text {th }}$ century) and Abul Qasim Firdawsi (ca. 940-ca. 1020), these Indians are called "Luli " or "Zott "8. The Muslim identity of the Balkan Roma has been acquired only after the Ottoman conquest of the Balkans at the end of the $14^{\text {th }}$ century. Regarding their affiliation to Sufi orders, monographic researches on this topic are lacking, but it seems that Sufi brotherhoods spread among Balkan Roma mostly in the interwar period, and that the number of Rom shaykhs increased in Macedonia only after the Second World War. Alexandre Popovic, observing the flourishing of takiya (Sufi centers) among Macedonian Gypsies in the $20^{\text {th }}$ century, remarks that the role acquired by Gypsy shaykhs was favoured by the migration to Turkey of the local Turkish populations and Sufi masters, whose vacant places were occupied by Gypsy shaykhs, and by the positive attitude of the ZIDRA (Zajednica Islamskih Derviških Redova Alije), the official association of Sufi orders in Yugoslavia, willing to increase the number of his members 9 .

Roma have a different, "elective" point of view about such a crucial issue as their religious origins, whose veracity is not relevant here. They assert that

ginning of the $20^{\text {th }}$ century. See Clayer (Nathalie), Mystiques, État et société. Les Halvetis dans l'aire balkanique de la fin du XVeme siècle à nos jours, Leiden : Brill, 1994, p. 255 ; De Jong (F), "Khalwatiyya ", Encyclopédie de l'Islam, volume IV, Leiden / London : Brill / Luzac \& Co., 1978.

${ }^{8}$ Lewis (G. L.), "Cingàne ", The Encyclopaedia of Islam, n. e., vol. II, Leiden / London: Brill / Luzac \& Co., 1965 ; Minorsky (V.) [I. P. Elwell-Sutton], " Lüli ". The Encyclopaedia of Islam, n. e., vol. V, 1986, Leiden: Brill, 1986 ; Walker (J.), " Nûrî ". The Encyclopaedia of Islam, n. e., vol. VIII, Leiden / London: Brill / Luzac \& Co., 1995 .

9 Personal communication of Alexandre Popovic. See also Popovic (Alexandre), " Les Balkans post-ottomans " in Popovic (Alexandre), Veinstein (Gilles), eds., Les Voies d'Allah. Les ordres mystiques dans le monde musulman des origines à aujourd'hui, Paris : Fayard, 1996 ; Clayer (Nathalie), op.cit., pp. 303-305. 
the first Rom who became Muslim took the bay'at (oath of initiation) directly from the hands of Muhammad, that he was thus a companion of the Prophet, a member of the highest spiritual and religious Muslim elite, who, like the Prophet himself, made of itinerant work his main source of income. Nomadism offers to the Rom another sound level of analogy. This real or/and symbolical analogy and elective affinity is based on the fact that nomadism and its implications, such as the rejection of permanent residence and goods, are essential and noble attributes of both the dervish and the Roma.

At the technological-artistic and professional level, and without suggesting any direct influence as far as the Balkans are concerned, one can observe that Sufis and Roma present strong analogies. A clear example is constituted by the so called be-shar' (heterodox) Indian Sufi orders. For various reasons, both the be-shar' Sufis and the Roma occupy low positions in the social hierarchy. In India, some be-shar' orders, such as those of musicians, are commonly assimilated to a low caste ${ }^{10}$. There are other similarities between be-shar' Sufis and Roma, such as the practice of professions connected to the alchemic technology (metal working, etc.), the transmission of various esoteric and healing skills, the professional and ritual use of music and other arts, the practice of artistic occupations (jugglers, etc.) ${ }^{11}$. Both groups are wandering ones. Obviously, such analogies are not confined to the Indian subcontinent and its heterodox Sufi orders ${ }^{12}$. For example, the popular music played by Balkan and Macedonian Gypsies, bears elements which may recall the music played by Ottoman Sufi orders and the military hymns of the Janissaries in particular ${ }^{13}$. An open question remains whether, in recent times, such analogies in the professional domain may have played a role in the process of assimilation of Sufism by the Roma in the Balkans, all the more that the link existing between

\footnotetext{
10 Gaborieau (Marc), " Les ordres mystiques dans le sous-continent indien, Un point de vue ethnologique ", in Popovic (Alexandre), Veinstein (Gilles), eds., Les ordres mystiques dans l'Islam. Cheminement et situation actuelle, Paris : EHESS, 1986, pp.111, 122-123.

"On Indian Sufi orders, see Sharif-Herklots (Ja'far), Islam in India or the Oanun-i islam, Delhi : Atlantic Publishers, 1999 (new edition revised and rearranged, with additions by W. Crooke, or. ed. 1832), p. 289 sq. ; Digby (Simon), " Qalandars and Related Groups. Elements of Social Deviance in the Religious Life of the Delhi Sultanate of the Thirteenth and Fourtheenth Centuries ", in Friedmann (Yohanan), ed., Islam in Asia, vol. I, Jerusalem : The Magnes Press / Hebrew University, 1984.

12 Other interesting information come from the study of the secret languages and jargons of vagabonds, beggars and Gypsy groups in various regions of the Islamic world, although conclusions are not univocal. Wladimir Ivanow, who carried his field investigations in the period around the First World War, wrote that many words in the language of the Gypsies of Qainat (between modern Iran and Afghanistan) " are used in the secrete code of dervishes, beggars, and, I believe, thieves $n$. Ivanow (Wladimir), " On the Language of the Gypsies of Qainat (in Eastern Persia) ", Journal of the Asiatic Society of Bengal, n.s., 10, 1914, Pp. 442, 445 ; for a wider discussion of this topic see Bosworth (Clifford Edmond) The Mediaeval Islamic Undenworld. The Bänú Säsân in Arabic Society and Literature, Leiden : Brill, 1976, volume I, pp. 169-171, 176-179.
}

13 Traditionally, Roma used to sell horses to the Ottoman military forces. 
Sufi orders and certain jobs, crafts or artistic professions like musicians represents also a means trough which Sufi orders rooted themselves into local groups and societies ${ }^{14}$.

The Rom and the Muslim identities may clash with each other at different levels. Lying, stealing, or sending children to school have completely different meanings whether interpreted in the Rom or Muslim frame of thought. Roma do not know the concept of private property : stealing something from a Gagi is not perceived as a criminal or sinful act. As Baba Jevat told me during one of the meetings I had with him : "Roma do not know Allah, they have no fear, no shame, that's why they need to be educated in Islam ". Except one family who is affiliated to the Jehovah's Witnesses, all the residents of the camp are formally Muslims, even if their compliance to the Shari'a (Islamic law) can be quite limited. Muslim Roma have a deep religious feeling that pervades many aspects of their life, but at the same time many of them may drink alcohol. They give Muslim names to their children, most of them fast during Ramadan and attend to the prayers at the camp mosque during this month and for other important religious celebrations. However, fewer of them attend the five daily prayers offered by Jevat, his relatives and closer disciples. Various families of Roma have strongly internalised their affiliation to Balkan Sufi orders, and some families of the Poderaccio camp bear Sufi family names. Appellations such as Kadiri and Halweti came to identify the main structural component and the centre of the Rom society and life : the family. Their cult of Muslim Saints may be considered analogous to that of Christian Saints practised by other Gypsies, and on the very Italian territory, the shrines of some Christian Saints are well known for being the place of large Gypsy gatherings during the Saint's anniversary ${ }^{15}$. On the day of Saint George's anniversary, some Muslim Gypsies of Florence wear green clothes and celebrate Khidr (The Green One) ${ }^{16}$, who is often associated with this Christian Saint. Important differences exist, however, since Muslim Roma have no shrines in Italy and the rituals described below have no equivalent in the religious customs of Christian Gypsies.

As in many other Gypsy camps in Italy, the level of criminality and social deviance is quite high, especially at the Masini camp. But it would be wrong to consider the deviant behaviours of the Gypsies only as the result of their lack

\footnotetext{
${ }^{14}$ Even today in a land of migration as Italy, certain strong connections between ethnic Sufi orders and professions can be observed ; for example, many Senegalese immigrants disciples of the Muridiyya order are pedlars, while most of the Egyptians disciples of the Shadhiliyya in Florence are pizzaioli (pizza makers), cooks and bakers.

${ }^{15}$ An example is the shrine and the anniversary of the Saints Cosma and Damiano in the town of Riace, in Calabria.

${ }^{16} \mathrm{Khidr}$ is an initiatory figure to which, according to the Sufis, refers the Qur'an in connection with Moses (XVIII : 59-81). He is connected with green, the highest symbolical colour in Islam. Many Sufis were initiated by Khidr during uwaysî states (see note 19).
} 
of respect toward the Gagi social rules and of other similar prejudices. Besides the frequently forgotten Nazi persecution during the Second World War, which stands as the example of the non existing political power of the Gypsies, it would be too long here to list all the forms of intolerance, discrimination and persecution that have been and are still perpetrated against Gypsies in our "civilised" societies. The social deviance of Gypsies living in Western Europe is the product of their assimilation to local discriminated minorities and sub-cultures, and is also related to the loss of their traditional identity, especially at work. The traditional occupations transmitted for centuries among Gypsies, such as metal working based on alchemical technology, smith, coppersmith, farrier, engraver, etc., artistic occupations (circus shows, itinerant orchestra, etc.) and nomadic trade of goods among isolated villages, have lost most of their role in contemporary Italian society. Only few of these professions survive, such as professional music groups playing also in the streets, and the ancient divinatory art of chiromancy, still widely practiced by women as their main source of income. This loss of professional identity is not merely a material issue, but first of all a psychological one, since in traditional societies, alchemical and artistic occupations represented a mean for personal and spiritual realization. The passage from a culture that did not know the concept of accumulating goods and money to a culture where their possession marks social differences, redefines the role of traditional authority, once based on age, knowledge and experience ; it encourages criminal activities, social deviance and/or economic dependence from the welfare state of the Gagi society. Some Roma of the camp have started to find other sources of income, especially through the opening of co-operative societies providing various kinds of services. Jevat himself works in a co-operative society financed by the Municipality of Florence that keeps watch on the entrance of the camp 24 hours a day. His second son works in a co-operative society cleaning institutional buildings such as schools and hospitals. His third son works in the family bar and in a cooperative helping immigrants to look for a job.

\section{SHAYKH BABA JEVAT'S SPIRITUAL AND SOCIAL AUTHORITY}

Baba Jevat was born in Skopje and today he is in his fifties. His family had stopped being nomadic two generations earlier. As Jevat said : " Thanks also to Tito, I have two houses in Skopje ". However, his family was still practising a traditional Rom occupation, horse-breeding, and Jevat himself has spent his adolescence watching horses. In 1973, he had his first encounter with his shaykh, Baba Najib. Baba Najib was a friend of his maternal grandfather and once came to his home to treat Jevat while he was ill. Soon afterwards, he took 
the bay'at with Baba Najib and developed a strong interest in the qasa'id (sing. : qasida), the spiritual poems which are sung during Sufi rituals. Baba Najib is also a Rom and a shaykh of the Khalwatiyya order ${ }^{17}$; he is still alive and Jevat visits him when he goes to Skopje, at least once a year.

Jevat discovered what it means to be a nomad when he migrated in Italy in 1981, looking for job, with his wife, children and the families of his three brothers. They were illegal immigrants, moving between Naples, Campania, Puglia and Calabria, and surviving by doing hard and irregular works such as seasonal farm workers. They returned to Macedonia in 1984. They came back to Italy in 1986 and applied for a permesso di soggiorno (residence permit), the document conferring the status of legal immigrant and opening the possibility of getting a regular job. They obtained this document and moved to the richer province of Pisa, before settling down in Florence in 1987. In the Poderaccio camp, next to his house, Jevat built a mosque that serves also as a takiya (Sufi centre) and opened a bar where no alcohol is served. The mosque established by Jevat at the Poderaccio camp was the first mosque built in Florence, and it remained the only one until 1989-1990, when a space for the Friday prayer was offered by the International Student Centre Giorgio La Pira.

In 1994, while being back in Macedonia, Jevat received from Baba Najib the khilafa (investiture) to initiate disciples into the Khalwatiyya. Jevat says that he did not make any request to his master, since he did not believe that his spiritual rank was high enough for this task. But his master said that his khilafa was the expression of God's will and that it was Jevat's duty to take care of the souls of his community in Italy. The choice of his master was also clearly determined by the fact that, since the 1990s, Jevat had had several initiatory dreams and spiritual encounters with eminent Saints and even with Hasan alBasri ${ }^{18}$. These spiritual encounters, in the style of the uwaysi initiation ${ }^{19}$, and the khilafa received from his shaykh are the main sources of Jevat's spiritual and religious authority.

Since he has become a shaykh. Jevat has given the bay'at into the Khalwatiyya to more than 40 Gypsies living in Italy, and the camp mosque be-

\footnotetext{
${ }^{17}$ The order traces its origins to the figure of 'Umar al-Khatwati (d. ca. 1397-1398), whose name refers to the custom of the spiritual retreat (khalwa). The master of Baba Najib was Baba Haydar who was a Turk and not a Rom.

${ }^{18}$ Hasan al-Basri (ca. 642-728) was the son of a freed female slave of Umm Salama (the Prophet's wife) ; he became the great imam of Basra, and one of the great hadith masters of his time (hadith are sayings and deeds of the Prophet).

19 From the name of Uways al-Qarani, a contemporary of the Prophet who became Muslim but never met Muhammad. The term became a synonymous for the Sufi spiritual and visionary initiation without any physical contact. The uwaysi initiation is traditionally regarded as being of a higher spiritual level than the ordinary one.
} 
came also the takiya of the group ${ }^{20}$. Many other people visit him and ask for his spiritual mediation without being formally initiated into the Sufi order. Most of them are from Macedonia and Kosovo and live in the Poderaccio and Masini camps, others come from various Gypsy camps in Tuscany and Italy. Only a certain number of persons who approach Jevat formally enter into the Khalwatiyya by means of a ritual of initiation. Some of them perceive and make this choice as a means for the salvation of their souls. Being taken under Jevat's spiritual protection is a way to escape problems such as alcohol and drug addiction, criminal behaviour or domestic violence. Therefore, for the new murid (disciple), entering the Sufi order represent also a way to redefine his personal identity and construct a new one fitting better with the social order and its ethical principles, that is not only with Islamic law but also with the Western rules. Several of Jevat's disciples in Florence need a strong authority that can direct them not only on the spiritual path, but also in their daily actions.

The range of religious and social functions played by Baba Jevat is wide. $\mathrm{He}$ is the embodiment of the typical Sufi master, who is a mediator between the human and the spiritual worlds, as well as a social mediator. The fact that Jevat knows well the Romanè language, speaks some Turkish and knows the Islamic traditions and those of his community defines him as a high authority. Roma turn to him for all kinds of difficulties. He often plays the role of an arbitrator in the frequent conflicts opposing some families and ethnic groups. In cases of bride abduction, the members of the two families gather for hours in Jevat's house to look for an agreement. Baba Jevat is also the spokesman of his community with the Municipality of Florence and other Italian institutions. Nevertheless, the authority exerted by Jevat in the Poderaccio camp itself remains limited and adapted to Rom cultural framework. As a whole, the Rom society lacks any central hierarchy, and each elder man is actually the only chief of his own family group. Ethnical divides are also strong among Roma. This social fragmentation has often prevented Roma from uniting their efforts for the achievement of common aims, especially in regard to state institutions. Roma turn to Jevat if they need his mediation during critical life events like illness or family conflicts, but he could not prevent the selling of alcohol in another bar inside the camp.

Being the main Rom Muslim religious authority in Florence, Jevat is frequently invited to lead religious ceremonies by the Khorakhane living in the city. He is also often called by Roma living in other Italian cities such as Naples,

${ }^{20}$ It can be observed that the khalwati group of Florence is structured in the typical decentralised way that has characterised the development of the Khalwatiyya (see Clayer (Nathalie), op.cit., p. 23 sq.). The Florence group and his master do not depend from the asitane (headquarter) of the order in Macedonia, the only connection with the original spiritual authority is maintained by Jevat, who visits his masters when he goes to Skopje. 
Bolzano, Trento or Pisa. One of the most frequent reasons for such invitations is the circumcision of young boys. Jevat does not make the surgery, but he performs the religious rituals and the prayers before the child enters the hospital ; some Roma were circumcised by specialists coming from the Balkans. Jevat treats also many Roma, be they adults or young children brought by their parents. Some people are possessed by a jinn (genius, demon). Once, I was told, a van with five passengers arrived to the camp. They had been driving from Naples for several hours. In the back of the van, an eighteen year old guy was lying, fastened with ropes; he was possessed by a dangerous and violent jinn. When Jevat opened the back door of the van, the man staying nearby stepped back, but the young guy was suddenly calm. Jevat untied him and took him into the mosque where he recited the Qur'an and other prayers; the day after the young guy had recovered. For difficult cases and powerful jinn, he also writes amulets ${ }^{21}$.

Besides the ones who have entered the Sufi order in order to change their lifestyle, there is a small bunch of disciples who can be regarded as the true spiritual murids of Baba Jevat. Most of them are part of the Gypsy elite that is better integrated into the Italian society. They follow the individual methods of meditation of the order, they learn the qasa'id of the order. As already mentioned, Jevat has also initiated a few Italians into the Khalwatiyya. For some of them, it has been an intense personal experience. One of them, before meeting Jevat, had dreamt about a man in a mosque and heard a voice saying that, in order to be saved, he should go to this place. When he arrived to the camp mosque he recognised it as the mosque he had dreamt about. Jevat was in Spain at that time, and the man had to wait a couple of days before realising that he was also the man he had dreamt about. Other Italian disciples of various Sufi orders periodically took part to the hadra (Sufi ceremony) in the camp mosque, to which intellectuals, artists and social workers interested in Sufi and Gypsy ceremonies have been also occasionally invited.

For the Italians, Jevat embodies a double and overlapping archetypal figure, since he is at the same time a Sufi and a Gypsy, two figures that in the Western imagination symbolise the mediator with the spiritual realms ${ }^{22}$. Sufi rituals enable the Rom group and the Italians to interact within a sphere, the

\footnotetext{
${ }^{21}$ Jevat's healing and talismanic skills, his control over the jinns and the allied knowledge that he received from his master, may be related to the traditional association that the Khalwatiyya order has with the transmission of esoteric and occult sciences. See Clayer (Nathalie), "La Khalwatiyya (Khalvetiye) ", in Popovic (Alexandre), Veinstein (Gilles), eds., Les Voies d'Allah (op.cit.).

${ }^{22}$ René Guénon, an author considered as an authority of esoteric doctrines by certain Italian and European milieus, quotes Saint-Yves d'Alveydre's (1910) and Ossendowski's (1924) travel books and the accounts they refer to, according to which Gypsies were once living in the mysterious and subterranean in itiatic centre of Agarttha. Guénon (Renë), Il re del mondo, Milano : Adelphi, 1977, p.12 [ed. or. : Le Roi du Monde, Paris : Gallimard, 1958].
} 
religious one, which is usually closed and banished to non-Roma. Furthermore, the fact that he is regarded as a master by the Gagi who usually discriminate Roma, confirms and reinforces his role as a shaykh within his own community. However, in other significant cases, the boundaries around the religious life of the group are not easily permeable for outsiders. Jevat's group (as other ethnic Sufi groups existing in Italy) do not interact with other non-Rom Muslims and Sufis, and have no significant relations with the other ethnic Sufi orders settled in Florence and Tuscany, such as the Shadhiliyya from Egypt and the Muridiyya from Senegal ${ }^{23}$.

In the 1990s, the Sufi rituals held in the camp mosque experienced a considerable vitality ; the hadra was held twice a week. During important religious celebrations such as the 'id al-Kabir (Abraham's Sacrifice) or the Maulid alNabi (Prophet Muhammad's birthday), it was not uncommon to see fifty or more men assembled in the mosque, performing dhikr (repeated invocation of God's name) during the hadra, as well as some women, who have their own space for prayer at the entrance of the mosque, that can be also separated by a curtain. The dhikr-i dawrani (circular dhikr) was also held quite often. During the first part of the collective dhikr the disciples assemble in a circle and remain seated invoking the dhikr ; then, they stand up and some of them form a whirling circle inside the main external circle, with Jevat standing in the middle of the internal circle, stressing with cymbals the rhythm of the dhikr. Qasa'id are sung during the ritual. Some of these dhikr can last from the evening until short before the fajr prayer (first daily prayer at dawn). The ritual of initiation of a new disciple usually takes place just before the hadra and it is a long ritual. The novice is carried by two elder disciples standing on his sides and holding him by the harms. They approach Jevat by walking slowly from the entrance door of the takiya; at each step they stop and recite invocations. At the end the novice reaches the feet of his shaykh. Jevat covers himself and the new disciple with a black cloth and, while covered, gives him the bay'at. During important hadra, Jevat leads also the shish (pike) or ijrah ceremony, during which he pierces his disciples with blades and pikes. Few of his disciples have the permission to pierce themselves with their hands 24 .

The hadra is a melting-pot of languages, and observing it offers a powerful insight into the composite structure of the Rom Islamic identity : dhikr and invocations are in Arabic, the $d u^{\prime} a^{\prime}$ (prayers) are in Romanè, the qasa'id are in

\footnotetext{
23 On the diffusion of Sufi orders in Italy and the contacts / boundaries among different ethnic Soufi Groups and between them and the members of the non-ethnic Sufi orders, see Speziale (Fabrizio), "I sentieri di Allah : aspetti della diffusione dell'Islam delle confraternite in Italia n, La Critica Sociologica, (135), automne 2000 .

24 For a description of this ritual held during the night of the 'Id al-kabir, see Speziale (Fabrizio), Passalacqua (Elisabetta), "I rituali sûfi dhikr e shish. Il caso della confraternita Khalwatiyya di Firenze ", Antropologia Medica, 2 (5-6), octobre 1998.
} 
Turkish, Bosnian, Romanè and even Persian. Another important celebration observed by the group and his master, even though they are Sunni Muslims, is the celebration of Muharram (first month of the Islamic calendar). As a Sufi, Jevat has a particular veneration for 'Ali and his family ${ }^{25}$. During the ten days that precede the Ashura ( $10^{\text {th }}$ of Muharram $^{26}$ ), he and a group of his relatives and disciples symbolically share the tragic destiny of Husayn by eating only raw food and drinking only rain water. During this period of time, they do not change their dresses, nor watch television, nor listen to music or having sexual intercourse.

\section{SHEYKH BABA JEVAT AND THE CHALLENGE OF ISLAMIC REFORMISM}

Since the late 1990s, Baba Jevat's authority and the religious life of his group of disciples have been threatened by various factors. The first one comes from within the Rom community and is represented by other Sufi groups. In the Poderaccio camp, as well as in other Rom camps in Tuscany and in Italy, there are also masters and disciples of different Sufi orders, in particular the Qadiriyya, the Rifa'iyya and the Sinaniyya, the latter being another branch of the Khalwatiyya. The affiliation to a particular order often reflects ethnic, but also kinship divides ${ }^{27}$; the Roma from Kosovo, for example, are mostly affiliated to the Qadiriyya since a Qadiri shaykh from Kosovo was living in Palermo in the 1990 os. Some families from Kosovo living in the Poderaccio camp are disciples of this shaykh, who came several times to visit them in the late 1990 . They also took part to the khalwati hadra lead by Jevat who offered also his takiya to the Qadiri shaykh to perform dhikr with his disciples, but the shaykh refused and decided to open another mosque in the camp, in the house of one of

\footnotetext{
25 'Ali ibn Abi Talib (ca. 599-661) was the cousin and son-in-law of the Prophet. He is considered by Shi'a Muslims as their first Imam and the first rightful Caliph. He had two sons, Hasan and Husayn, with the daughter of the Prophet Fatima. Husayn (ca. 626-680) and his family were killed by the troops of the Umayyad Caliph Yazid during the battle of Karbala on 10 October 680 (10 ${ }^{\text {th }}$ of Muharram). Most Sunni Sufi orders consider 'Ali as the first to whom the Prophet Muhammad transmitted the dhikr and the esoteric knowledge connected with Sufism.
}

${ }^{26}$ On the $10^{\text {th }}$ of Muharram, Shi'a Muslims celebrate the anniversary of the martyrdom of Husayn (see note 25), whom they consider as their third Imam. Sunni Muslims do not celebrate Husayn's martyrdom, but commemorate the Ashura as the day on which Noah's ark survived the Flood and when the Jews led by Moses left Egypt for the Sinai peninsula (Ashura corresponds also to the Jewish Yom Kippur).

27 On the role of ethnic networks within Balkan Sufi orders, see Popovic (Alexandre), art.cit. 
his disciples. However, this mosque was closed a few years later, after the Qadiri shaykh had left for Germany ${ }^{28}$.

But the main interethnic conflicts in the Poderaccio camp have been fed by external factors, such as the building of new houses for the Roma in Florence, a project run by the Municipality and funded by the European Union. The Municipality built a first group of houses in one of the city suburbs, and some members of Jevat's family moved in when they were finished in 1998. But, soon afterwards, protests organized by the inhabitants of these suburbs led to the cancellation of the project, and the construction of the other houses was stopped. Even though Florence and Tuscany are ruled by a left-wing coalition, local politicians preferred to give back the European funds than to loose votes. Most of the Roma who recently settled in Italy have no right to vote at local and national elections, so that they have a very limited influence on political parties. Jevat was attacked by other Roma in the camp, since his family had taken the only houses that had been finished. For this reason, Jevat remained in the camp with his wife and sent his two sons and his daughter to live in the new houses. But this was not enough to calm the situation and several persons, mostly from Kosovo, stopped to attend the hadra.

The main challenge to the religious life of the group, however, was the interaction with the Arab and Moroccan imams of the new mosques opened in Florence in the recent years. Many of the mosques established in the last decade in Italy have been funded by Saudi Arabia and other Arab countries. As a consequence, Wahhabism and the related anti-mystic attitude (typical of other Islamic reformist movements as well) ${ }^{29}$, constitute the ideological leaning of many imams appointed in these mosques. These reformist-minded imams condemn religious orders, as did the Protestants in the $16^{\text {th }}$ century. They regard the Sufis and their miracles as superstitious heritages of the past to be banished. In the beginning, Jevat himself encouraged some members of his community to visit the new mosque when being in the city, all the more that, at the same period, a group of Jehovah's witnesses began to visit the camp with the aim to convert Muslim Roma ${ }^{30}$. But Jevat's spiritual authority, based

${ }^{28}$ Some other Roma living in Florence and Tuscany have recently become shaykh, some of them probably through family acquaintances. In the Poderaccio camp, a Rom from Macedonia has recently become shaykh of the Rifa iyya order, but he drinks alcohol and regularly attend the khalwati dhikr led by Jevat. In western Tuscany, near Livorno, there is also a young shaykh of the Sinaniyya order. About the situation in Palermo, see Soustre de Condat (Daniell), op.cit.

29 Wahhabism is a Sunni fundamentalist sect named after his founder Muhammad Ibn Abd al-Wahhab (d. 1792) ; the sect allied with the rulers of Saudi Arabia where it become the official religious doctrine. Wahhabis oppose all forms of Islamic esoteric and mystic thought and the rituals traditionally connected to them, such as the cult of Sufi Saints and shaykh and the pilgrimage to their shrines. Anti-mystic views are also characteristic for other reformist and modernist movements which appeared in the Muslim world during the Colonial period, such as the Ahl-i Hadith (People of the Hadith) in India.

${ }^{30}$ Conversion to Christianity is not uncommon among Muslim Roma, and is perceived as a way to inte- 
on initiation and personal gnostic experience, was challenged by a new model of religious authority based on the knowledge of Arabic language, the Qur'an and the Sunna (Islamic tradition). Muslim Roma usually have a rather limited, personal and orally transmitted knowledge of Islam and the Sunna. For example, one of Jevat's disciples told me once a hadith (saying or deed of the Prophet), starting with : " The Prophet and 'Ali were travelling together by bus when the Prophet said... ". Therefore, Arab imams could easily gain a certain influence among the Roma who started to go to the mosque in the city. Arab imams had a strong set of criticisms against Sufis and their rituals. Jevat's personal style, the respectful way in which his disciples treated him, the ecstatic behaviours during the dhikr in the camp mosque, the same fact that the mosque was also a takiya, offered arguments for such criticisms. Some Roma frequenting the mosque started complaining about their wives and daughters since they did not cover their head, or were seduced by the anti-American qutbas (Friday sermons) of some imams ${ }^{31}$. The clash between the imams' views and Jevat's Sufi identity and rituals was inevitable and represents only the local version of a conflict that has pervaded most of the Muslim world in the $20^{\text {th }}$ century.

It is important to note that Jevat had never been faced with Wahhabi ideas before. When he left for Italy, Wahhabism was rather unpopular in Macedonia and Sufis were the main traditional religious authorities. In the year 2000 , Jevat invited several times the imams to come to pray in his mosque ; they came a couple of times and attended the dhikr. They criticised Jevat's personal style as being based on the cult of the shaykh, and his role of mediator with God. They blamed Sufi rituals during the hadra for being non-Islamic. They accused Jevat and his disciples of being Shi'a Muslims, since they celebrated Muharram and recited prayers for 'Ali and the Shi'a imams during the hadra. Jevat's second son, Merkes, the one designated by his father to succeed him as the shaykh in the Sufi order, wants to become the imam of his community, and the imams offered him to apply for a scholarship to study in Saudi Arabia, but, at the end, he renounced.

The interaction with the Arab imams of Florence and their criticisms has deconstructed and reshaped the religious identity of the group at different levels. The adab (rules) inside the takiya and toward the shaykh has considerably changed. The reverential behaviour of the murids towards Baba Jevat, based on the model of the master-disciples relationship that can be observed in most takiya in the Balkans, has been completely redefined. Before, all the medieval phobias against Islam and the Muslims.

${ }^{31}$ One of the Moroccan imams was briefly put in jail by the Italian police in the wake of the terrorist attacks in New York on 12 September 2001, but he was soon released and freed from all accusations. 
disciples were used to bow in front of Jevat, to kiss his right hand, or even his feet. They always stood up when Jevat did so and never sat in his presence. Disciples never walked turning their back to the shaykh, but always went backwards. Now, only few disciples still observe these rules. The Sufi atmosphere of the takiya has considerably changed. All the pictures of Saints and Sufis, as well as those of the Shi'a imams (a heritage of the Iranian influence in the Balkans) and of Jalaluddin Rumi's ${ }^{2}$ shrine in Konya, have been taken out from the takiya. Only the calligraphies of the Qur'an, the pictures of Mecca and of the Prophet's shrine in Medina and a small naqsh (talisman) of 'Abd al-Oadir al-Jilani 33 still hang on the walls. Before, as it is the case in the Balkans, it was normal to smoke in the takiya, and Jevat used to offer cigarettes to his guests and disciples. Cigarettes, coffee and tea accompanied the long discussions on religious issues between Jevat and his disciples, before and after the hadra. Smoking was banned after the imams complained that the takiya was first of all a mosque, in which smoking was not allowed. The celebration of the hadra underwent also important changes. The most significant one is that the longer and more animated part of the ritual, when the assembly stand up, was not performed anymore. The last three times that I visited the camp the dhikr was performed only in the sitting position.

However, Jevat says that his relation with the Arab imams is not one of conflict and that they never denied his religious authority. After a phase of adaptation, Jevat has learned how to counter Wahhabi types of criticisms. His knowledge of the Sunna, however restricted in comparison to that of the imams, enabled him nonetheless to understand that Wahhabi arguments are often based on rather individual interpretations of the Sunna, and that there are many authentic traditions and legitimate interpretations that can be used to reveal their weaknesses. At that time, it seems that it was also important for Jevat to strengthen his relationship with Italian Sufis, whose strong and detailed criticisms of Wahhabism provided him with sound additional arguments to use with the imams.

An important event that has contributed to redefine Jevat's relation with the Arab imams is his participation to the hajj (pilgrimage to Mecca) in 2003, together with a group of Arab immigrants living in Florence and some imams of the city mosques. According to Jevat's account, the imams were highly surprised to see that he was praying even more than they were and that he could offer such a deep interpretation of Islamic beliefs and rituals, quoting great theologians, poets and Sufis unknown to the Wahhabis. Jevat told me that he

32 Jalaluddin Rumi (1207-1273) was born in the Persian city of Balkh, and died in the Anatolian city of Konya. He is one of the greatest Sufi poets, and his major work, the Mathnawi al-Manavi (Spiritual Couplets), is regarded as one of the masterpieces of Persian mystical literature.

33 'Abd al-Qadir al-Jilani (1083-1166) is the founder of the Qadiriyya order. 
was really surprised when he understood that the Wahabbi imams ignored completely the sayings of religious authorities such as Ibn al-Arabi34, Rumi or Yunus Emre35, all authors whom Jevat can quote by hearth. It seems that also for the imams and the other pilgrims from Florence, it had been difficult not to perceive the spiritual strength of his Sufi religious style, even though he did not speak Arabic. One day, a small group of them made the salah (daily prayer) in the Prophet's mosque in Medina. After the salah, Jevat started to recite some additional prayers for the Prophet Muhammad. A voice from their back began to reply to Jevat's invocations. Once he had finished, somebody tried to see the one who had joined the prayer, but nobody was there. Somebody said that it could have been the voice of an angel, and this strange event gave to Jevat a scent of saintliness. When I visited again the camp in 2003, one of Jevat's disciples who go to the mosque in the city told proudly that some Arabs there were saying that Jevat has a higher spiritual rank that all the imams of Florence. Jevat himself had decided to celebrate again Muharram, notwithstanding the imams' criticisms, replying that this is not only the month of Husayn's martyrdom, but also the month when Adam was left on the earth, when Noah was saved and when Moses escaped from Egypt ${ }^{36}$.

\section{CONCLUSION}

Jevat's ability to adapt his personal religious style and that of his group to the local circumstances can be regarded as a typical example of the Roma expertise in adapting themselves to foreign and difficult settings. The adaptation capacity has always been an essential resource for the Roma who are constantly changing their place of residence and have to interact with various environments and cultures which are usually discriminating them as an underclass. The life of the Roma in Florence can be seen as a continual process of adaptation to and mediation with external rules. This process implies cultural changes at different levels. As already said, from a social point of view, the main adaptive efforts of the Roma are related to the labour market and to state institutions. The main alternative to criminality and dependence from the welfare state, that is co-operative work, is something that necessarily contri-

$34 \mathrm{Ibn}$ al-Arabi (1165-1240) was born in the Andalucian city of Murcia, and died in the city of Damascus. $\mathrm{He}$ is one of the greatest Sufi thinkers; among his numerous works are al-Futuhat al-Makkiyya (The Meccan Revelations), written during his pilgrimage to Mecca.

35 Yunus Emre was a Sufi poet living in Anatolia in the $13^{\text {th }}$ century.

${ }^{36}$ See note 26 . 
butes to modifying the traditional identity of the group. Many Khorakhane of the Poderaccio camp have applied for legal immigration documents and got registered at the Municipality in order to access to social housing, although this implies to split the enlarged family group into several parts.

Notwithstanding the empty promises of the past, Jevat still tries to mediate with the Municipality of Florence. In this way, the camp was connected to the municipal canalization and sewerage system, but Roma complain that it would have been cheaper to build a new camp. The Municipality has indeed decided to build a new camp with wooden-houses on a field beside the Poderaccio camp. The construction works have been finished by the half of 2004 and peoples moved in. The new camp has a "unique" wooden Mosque of seventy squared meters with bathrooms and an office. Here, Jevat's second son has started giving once a week dars (lessons) on Islamic topics to other Roma. By importing in Italy a Sufi order and its rituals, Jevat has given to the members of his community a powerful way to preserve important features of their religious identity in a foreign setting and, at the same time, a mean to deal with the growth of social deviance. Sufi rituals have also given rise to a set of relations with Italian Muslims and intellectuals that are completely different from the discriminatory ones that usually define the attitude of the Italian society toward the Gypsies. Finally, Jevat decided to adapt the religious style of his Sufi group to make it more suitable to the leaning of the new mainstream Islam in Italy.

Jevat did not meet with insuperable difficulties in adapting the dhikr and the behaviour of his disciples according to the requests of the imams. $\mathrm{He}$ thinks that he and his discriminated community have nothing to gain from an antagonist relationship with the local Islamic institutions; however, the recent supposed connections of some members of these Islamic Institutions with fundamentalist plans, may also have warned him of the risks connected with tight close relations with such elements. From a wider point of view, it has to be underlined that the changes that we may observe in the last years in the Florence group (decline of spiritual authority in the society, simplification and impoverishment of rituals, assimilations of reformist features, etc.) are similar to the main changes characterising in the whole Islamic world, and since the Colonial period, the adaptation of Sufi orders to modernity.

It is also important to note that some of the criticisms put forward by the imams are buttressing Jevat's own social and religious endeavours in the camp. For example, when the imams visited the camp he showed them that in his family bar no alcohol was sold, and in this way could mobilize their religious authority against the Roma selling alcohol in the other bar of the camp. The same pattern can be applied to other behaviours considered haram (forbidden, unlawful) in Islam, such as theft and other crimes. Shari'a, even in the guise of an Arab Wahhabi imam rejecting Sufism, is one of the strongest wea- 
pons that Jevat has for countering social deviance in the camp. The new relation that Jevat has developed with the imams of the city implies the relinquishment of a part of the religious identity and ritual life of the group. At the same time the Arab imams of the city have redefined their critical attitude towards Djevat and started to esteem his role among the Rom community. The new attitude of the imams has provided an additional external sanction to Jevat's religious authority among the Roma, and the whole process have opened the group to a wider set of relations with the Muslims of Florence. 